\title{
MIXED PENTOTHAL-CURARE-NITROUS OXIDE ANAESTHESIA FOR CHILDREN AND INFANTS: A TECHNIQUE AND DOSAGE SCALE FOR RAPID INTUBATION AND FOR MÁINTENANĆE*
}

\author{
Charles F. Egâ, M.B.E., M.D., C.M., M.SC., D.T,M.\&H. (Eng.), D.A."*
}

$\mathrm{O}_{\mathrm{NE}}$ of the most advantageous of the general anaesthetic combinations to arise from the introduction of curare by Griffith (14) was pentothal-curare-nit ous oxide. Moderate doses of these agents produce the main pharmacological efect of each '(hypnosis, relaxation, and analgesia) and are relatively free from the morbid side effects of comparable doses of the other general anaesthetic agents. However, these three agents together interfere with pulmoriary respiration to a far greater extent than do anaesthetically equivalent amounts of the other anaesthetics, i.e. respiratory centre depression by pentothal, "plus respiratory muscle paralysis by curare, plus reduction of compensatory oxygen gradients by effective concentrations of nitrous oxide. This seemingly great disadvantage is at once eliminated by adequate and continuous assisted or controlled véntilation throughout with over 20 per cent oxygen from a non-rebreathing system receiving a total flow of 8 litres per 'mmute of gases (nitrous oxide and oxygen). With adequate amounts of curare excellent relaxation for orotracheal intubation and/or abdominal surgery is obtained under light (plæne 1) anaesthesia. Thus the cells of the bram are subjected to only the minmum necéssary amcunt of interference with functional energy buld-up (ATP formation (23)) so that associated cellular oxidative processes and hence the vitality of not only the brain but also myocardıum, hver, kıdneys, endocrıne glands, etc. remain relatively unimpaired. The low total dosage of pentothal also keeps its hypotensive effect to a negligible minimum. The resemblance of pentothal-curare-nitrous oxide anaesthesia to natural sleep and artificial hibernation has been noted $(15,16)$

The technique of using pentothal mixed beforehand with curare in their optımum proportions (usually as "Baurd's solution" (1) of $500 \mathrm{mgm}$.- pentothal with $15 \mathrm{mgm}$. d-tubocurarine chloride in a $20 \mathrm{ml}$. syringe or a $500 \mathrm{ml}$. drip) while it does not give absolute control of either one, gives in return the advantage of technical simplicity with greater smoothness and exactness of over-all control. The overlapping effect of the main pharmacological properties of the three agents coupled with durect control over the concentration of nitous oxide gives a considerable degree of elasticity to fixed proportions of pentothal with curare, so that absolute dosage control over etther of the two drugs is not necessary. In the small percentage of cases where the nature of the patient or operation goes beyond the bounds of this elasticity fairly exact control is easily regained with an accordingly different mitial proportion of pentothal and curare or by injecting

'Presented before the Annual Meeting of the Canadian Anaesthetısts' Society, Vancouver, British Columbia, June 14-15, 1954

* From the Department of Anaesthesia, Children's Memorial Hospital and McGll University, Montreal, Quebec 
an additional amount of pentothal or curare into the tubing of the original mixture when the need becomes apparent. With opportune tapering off of the dosage before the end of operations, most patients have regained an adequate ventilation of their own and can therefore be extubated and are emerging a few minutes after the operation.

Despite the great preponderance of its advantages over its disadvantages in orotracheal intubation and abdominal surgery in adults, pentothal and curare have found only sporadic use in paediatric anaesthesia. The reason for this has probably been fear of the relatively narrower range of safety of drugs in children in the absence of a specific dosage scale ( $\mathrm{ml}$. mixed pentóthal-curare per lb. body wt.) for specific anaesthetic purposes (e,g., ml. of the mixture for orotracheal intubation). Each is usually given alone in small and uncertain quantities (31) generally as adjuvants to the other anaesthetic agents.- Volpitto (34) reported the intubation of children after rapid induction with mixed pentothal-curare but his mitial doses were insufficient to eliminate the danger of hypoxia from laryngeal closure. It was found that additional amounts ivere generally nèeded and periods up to ten mir utes were apt to elapse from initial. injection to intubation. His range of dosage was too indefinite to provide the safety of predictable results. On the other hand the use of cyclopropane, the only other powerful and relatively non-toxic general anaesthetic agent, is largely restricted especially in infants and small children by the resistance and the heat and water retention of closed systems and by the questionable reliability of complete carbon dioxide removal by soda-lime (2). Ethyl ether has thus remained the chief and in most places the only paediatric general anaesthetic agent regardless of its poisonous effects on the unstable metabolic-balances of children. There exists, therefore, a definute need in paediatric anaesthesia for the advantages provided by rapid intubation and mantenance with mixed pentothal-curare-nitrous oxide in adults It was therefore decided to study this technique in the oldest children and jradually extend it as far down the paediatric age scale as possible with sacety in an attempt to find a safe and relatively accurate scale of dosage of mixed pentothal-curare for rapid intubation and possibly mantenance.

At first, especially in some of the older children (10-14 yr. of age), different proportions of pentothal with curare were tried but it at once became apparent that the optimum mixture for children was the same as for adults (1). The amount of this pentothal-curare mixture needed for intubation of $100 \mathrm{lb}$. children (apparent age $14 \mathrm{yr}$.) when rapidly injected was expressed in ml./lb. body wt. and used to approximate the prelıminary rapid intubation dose for $90 \mathrm{lb}$. children (app. age $13 \mathrm{yr}$.) and so on down the weight-age scale. This preliminary clinical investigation was carried out through 90 operations requiring orotracheal intubation and/or abdominal relaxation in the patients ranging from 14 years of age almost to the newborn. A tolerance to an intubation dose of pentothal-curare relatively equivalent to that of adults and to subsequent maintenance doses equivalent to one-half that of adults was exhbited by all ages down to infants 1 year old $(20 \mathrm{lb}$.) As the investigation proceeded it became increasingly apparent that the minimum or optimum amount of rapidly injected pentothal- 
curare required for intubation was so closely related to body weight in children that it can be accurately and safely predicted. The usual technique of rapid intubation and 'maintenance with pentothal-curare-nitrous oxide in adults was, after a few additions and minor changes, made perfectly adaptable to children and infants.

\section{Yreliminary Consmerations}

The indicatıons, contra-indıcations, and possible complications of this technique in adults were used initially and in accordance with paediatric principles to govern rejection and conduct of cases. Further modifications and additions were made from the information gained in the investigation. The limited number of cases, however, requires that the findings be looked upon as provisional rather than proven. Most important of all, however, is the warning that it is equally as safe and in special cases actually safer (vide infrá) than the other methods only in the hands of a fully trained, skalled, and knowledgeable anaest netist providing adequate ventilation from the onset to recovery.

\section{Indications}

By the end of this investigation the impression was quite definite that this technique of rapid intubation and of maintenance with pentothal-curare-nitrous oxude was superior to all the lother types of anaesthesia for orotracheal intubation and/or abdominal surgery in' children and in infants over $20 \mathrm{lb}$. It provides better operative conditions (quieter respiration, smoother relaxation, and less oozing), less disturbances in paediatric physiology and biochemistry, and more, rapid recovery to complete normality.

(A) Conditions in the Patient

(1) Toxic states such as fever, acidosis, uraemia, dehydration, toxaemia, and electrolyte imbalance as seen in intestinal obstruction, infections, burns, renal disease, drabëtes, etc.

(2) Conditions requiring rapid induction and intubation for immediate seizure of control of the air passages.

(a) Fluids or food in the stomach.

(b) Passable partial obstruction of the upper respiratory tract before or durng induction. This includes such conditions as very swollen tonsils, copious secretions, persistent laryngeal stridor which wou.d not preclude good pulmonary oxygenation with pure oxygen -befo $e$ induction, may cause serious respiratory hypoxia during slow induction, but would not prevent direct laryngoscopy and intubation of the relaxed patient

\section{(B) Nature of the Operation}

With the exception of neurosurgery and thoracic surgery this technique of anaesthesia was employec in infants and children for operations representative of practically èvery type and site of surgery requiring intubation and/or re-

"In contrast to "Impassable" conditions slach as, fixed flexion of the head; ankylosis of mandible, etc. which prevent direct laryngoscopy and/or intubation of the relaxed patient. 
laxation. To illustrate this range a few typical examples and ages of this sernes of eases are listed.

The duration of these operations varied from 30 minutes to 4 hours. This methoid of pentothal-curare-nitrous oxıde anaesthesia was especially advantageous over other methods for the following types of procedures in children.

TABLE I

\begin{tabular}{|c|c|c|c|}
\hline Operation & Age of Patient & Operation & Age of Patient \\
\hline T.onsits and adenords & 14 years & Colostomy closure & 9 years \\
\hline Tonsils and adenonds & 6 years & Infussusception & 18 months \\
\hline Tonsts and adenoids & 18 months & $\begin{array}{l}\text { Laparotomy (nephritis } \\
\text { with temp. } 102^{\circ} \text { ) }\end{array}$ & 5 years \\
\hline Hair lip repáır & $\dot{b}$ months & Incarceiated ingurnal & \\
\hline Radical mastord & 10 months & hernıa & 8 months \\
\hline Bronchoscopy & 4 years & Appendectomy & 5 years \\
\hline Oesophagoscopy & 2 years & Orthopedic limb surgery & Where the position \\
\hline $\begin{array}{l}\text { Laparotomy (acute } \\
\text { pancreatitis without } \\
\text { shock) }\end{array}$ & 5 years & Lengthy skin graftings & $\begin{array}{l}\text { of the patient or } \\
\text { other factors made } \\
\text { intubation necessary }\end{array}$ \\
\hline
\end{tabular}

(1) Short procedures requaring intubation and orly 15 to 45 minutes, such as tonsillectơmy; are simply managed by a single. intubating dose of pentothal-curare in what is later referred to as the "single shot technique."

(2) Peroral endoscopic procedures that are expected to last well over 10 minutes.

(3) Abdominal operations, especially if the patient is systemically ill.

(4) Major surgery with cautery

(5) Lengthy operations especially in infants and younger children. The use of pentothal-curare for intubation and then for maintenance even of only the first half of 2- to -5-hour operations greatly reduces the amount of other agents and their adverse effects

There was no paediatric neurosurgery or thoracic surgery available at the time for this investigation. However, I have since used this technique for both types of surgery in small children with all of the advantages obtained in adults

(C) Anaesthetic Advantages

(1) The various degrees of "hypoxia and/or hypercarbia that usually accompany induction and intúbation by other methods and agents: especially in children are eliminated by this technique (19). The sudden and profounc relaxation of the jaw and larynx prevents laryngospasm and allows the immediate institution of adequate respiration (controlled)

(2) Barbiturate-relaxant-nitróns- oxide is thè only safe general anaesthetic for major paediatric surgery that is entirely free from the hazard of explosions in operating rooms and equipment not completely explosionproofed.

(3) Rapid intubation allows the surgical preparation of the patient to begin 90 seconds after the insertion of the needle of induction. This is particularly welcome in over-crowded operating schedules and for short procedures 
such as tonsillectomies where the time ordinarily needed for induction and intubation may approach that required for the surgery.

(4) The duration of emergence (end of operation until children opened their eyes on command or infants cried or otherwise reacted to a painful stimulus) averaged approximately 3 to 5 minutes-as short as emergence from cyelopropane and shorter than from ether. It was unaccompanied by the laryngospastio tendencies and the postoperative nausea and vomiting which are frequent when ether and cyclopropane are used.

(5) The intravenous puncture for injection encourages the use of intravenous fluids in infants and children.

(6) Eäh of the:other major paediatric general anaesthetic agents has' at least one specific and formidable drawback that is relatively absent from pentothal-curare-nitrous oxide in infants and children; e.g., the phosphoric acidosis $(5,28)$ and other adverse biochemical éffects $(12,29)$ of ether may reach dangerous proportions especially in predisposed children (21, 33).

\section{Contraindications}

(A) Conditions in the ratient

(1) Hypoxia of any type and cause not completely relieved by oxygen and/or other measures before induction.

(2) Even the possibility of "impassable" conditions of the respiratory tract, i.e. where immediate intubation and control of respiration of a relaxed patient cannot be guaranteed.

(3) Shock in any degrẹe.

(4) In progressivély snnaller infants (20 lb. and down) pentothal hypnosis increased considerably in duration (rather than depth). On the other hand the effects of curare lengthened only slightly. The duration of light pentothal hypnosis from the time of administration of an intubation dose of the pentothal-curare mixture was approximately $3 / 4$ hour in $20 \mathrm{lb}$. ( $12 \mathrm{mo}$.), 1 hour in $15 \mathrm{lb}$. ( $6 \mathrm{mo}$ ), and $1 \frac{1}{2}$ hours in $7 \mathrm{lb}$. (newborn) infants. The addition of any further amounts (maintenance doses) of the mixture increased considerably these durations of hypnosis. As a result the first patients remained asleep (but could be roused) for up to three hours postoperatively. In subsequent cases this was avoided and rapid emergence to normality was attained by restricting the use of this technique in small infants to operations with an expected duration of at least twice that of the expected hypnosis from an intubating dose. No further pentothal-curare mixture was given except in very long operations (3-5 hr.) where one or two maintenance doses were used before going on to ether. The amount of ether needed to maintain these patients was quite small. The smaller the infant the longer the persistence of the pentothal and thus the less the amount of ether needed for maintenance. Hence the seemingly paradoxical statement that the longer the operation and the younger the infant the greater the benefit (ether-sparing effect) of pentothal-curare. Shorter operations in infants under 6 months may be 
better managed by intubation prior to injection and then giving just enough pentothal-curare for surgery.

(5) Miscellaneous conditions such as wet lungs, bronchial asthma or related allergies, liver damage especially in infants, and the absence of available veins coupled with no indications for an intravenous cut-down.

\section{(B) Nature of the Operation}

This technique is impractical in paedıatric operations not requiring intubation or abdominal relaxation, and in ultra-short procedures (less than $15 \mathrm{~min}$.) in children or procedures of less than 1-1 $1 / 2$ hours in infants. Surgery of the orbit, side of the neck, or of the larynx may cause autonomic reflexes of sufficient intensity to make cardiac'arrest possible. In two ceses, a resection and recession operation in a child aged 6 years and a congenital torticollis in a child aged 7, the patients were intu sated under this pentothal-curare-nitrous oxide technique and carried in plane 1 anaesthesia. In both, the onset of surgery was accompanied by pronounced arrhythmias of the pulse regardless of good atropinization and oxygenation. Regular ventricular rhythm was only re-established by deepening the anaesthesia to mid-plane 2 by the addition of ether.

(C) Anaesthetic Contraindications and Disadvantages

(1) Rapid induction-intubation of infants and children with pentothal-curare would certainly be as dangerous in the hands of the uninitiated or inexperienced as it is safe and advantageous when under the control of the competent anaesthetist with experience in paediatric anaesthesia.

(2) Failure to have first-class equipment in proven workung order and all of it immediately at hand.

(3) The almost simultaneous administration of agents intravenously and by mask requires the presence of an assistant to manage either the mask or the venipuncture. However, once the technique has been so learned as to be nearly automatic one anaesthetist can manage it alone except in difficult cases.

(4) Blind nasal intubation is rendered difficult or unsuccessful by the absence of spontaneous respiration.

(5) Surgeons are easily frightened by the sudden disappearance of spontaneous breathing even though it is at once replaced by adequate controlled respiration.

Almost all of these anaesthetic disadvantages can be easily circumvented.

\section{Possible Complications}

There were no complications of note in this series and at no time was a patient in trouble. The following effects or "minor complications" were harmless and mostly mild and transient.

1. Pulse changes. A few seconds after rapid injection of the intubating dose there occurred a palpable moderate decrease in pulse rate and strength lasting 2 to 5 seconds in about one-quarter of the cases tested. No irregularities were felt. Laryngoscopy and intubation caused a moderate increase in pulse rate and strength in about one-half of the cases and occasionally a palpable transitory 
irregularity. The tendency of intubation to reverse the pulse effects of rapid injection back to normal was noticed.

2. Blood pressure changes were measured sphygmomanometrically in only a few cases and in approximately two-thirds of these a transient fall of 5-15 mm. of mercury in systolic pressure and a lesser amount in diastolic pressure was noted. Intubation was prone to cause a quick return to normal. The colour of all the patients was normal or somewhat paler than normal from rapid injection to intubation.

3 Respiratory changes. If the intubating dose of pentothal-curare was not given rapidly or was less than the required amount or if intubation was attempted before 30 seconds or later than 90 seconds after injection, the cords were liable to be mobile with a tendency to weak but bothersome closure on laryngoscopy. Intubation without first injecting a small extra amount of pentothal-curare in these cases would almost invariably result in a spastic thorax ("bronchospasm") or moderate bucking on the tube. Postoperative respiratory depression lasting more than 3 minutes was not common, but invariably the result of giving more pentothal-curare too near the end of an operation. Easy management of it by assisted respiration with oxygen made it a matter of no particular concern. On the other hand, its neglect would be lethal and inexcusable. Excessive respinatory tract secretions were uncommon and due to lack of atropinization, food or fluids in the stomach, or the presence of respiratory infection.

4. Prolonged postoperative hypnosis occurred only in the first of the small infants in this series and was due to overdosage of pentothal relative to their lesser ability to destroy 1t. These patients remained asleep for up to 3 hours but could be roused and had no overt respiratory depression.

5. Perivascular injection happened in one case as a result of reflex movement of the limb not being held firmly enough. The possibility of delayed respiratory depression from later absorption was kept in mind but the amount was apparently insufficient.

It would be more accurate to refer to these minor complications as "potential avenues to serious complications." The possible serious complications of this technique in children would likely be similar to those resulting from injudicious use and management of it in adults. These are cardiac arrest, "pentothal shock," respiratory anoxia, prolonged deep depression, and limb damage from intraarterial or perivascular injection. The causes of these are well known and obviously avoidable.

Currently, the most controversial objection to rapid injection and intubation with barbiturate-relaxant anaesthesia is the possibihty of cardiac arrest. In this method of anaesthesia in adults, disturbances in cardiac conduction commonly occur at any of four points: (i) during the transient wave of depression (deep anaesthesia) from the rapid injection (10,30); (ii) laryngoscopy and intubation $(8,10,25)$; (iii) surgical stimulation of cardiac reflex receptor areas (8); and (iv) endotracheal suction and extubation (11). Except for one (30) that may have been due to the rapid injection itself, no cases of cardiac arrest from this cause could be found in the literature. In fact Colon-Yordon et al. (10) as well 
as Converse et al. (11) employed rapid barbiturate-relaxant injection for intubation of over a thousand cases of cardiac and cardiovascular disease of almost every type and there were.no cardiac stoppages. The underlying causes of cardiac disturbances and of arrest under light general anaesthesia are well known $(8,9$, $25,35)$ and avoidable. The main aggravating factor is hypoxia. However, Krumperman et al. (19) showed that properly managed rapid injection and intubation produce very little alteration in blood oxygen and carbon dioxide compared to that produced by other methods such as ether induction. Furthermore, light anaesthesia for intubation is avoided by performing it within 30 to 60 seconds after rapid injection, i.e., before the transient wave of deep anaesthesia had thinned out by redistribution to plane 1. Finally, the important thing is an awareness that transient electrocardiographic disturbances are not uncommon in any type of general anaesthesia and that during light anaesthesia the existence of one or more aggravating factors can magnify these disturbances to a cardiac arrest. On the other hand deep anaesthesia itself can cause cardiac depression and arrest. Dripps et al. (18) nicely sum up this situation in their statements: "However, overzealous use of deep general anesthesia or cardiac depressant drugs in an attempt to prevent reflex circulatory alterations caused by intubation ultimately may be more detrimental to the patient than the condition that was to be avoided," and "The physician must never lose sight of the fact that catastrophies at the time of intubation are more likely to ensue from anoxia, overanesthetization or reactions to topical anesthesia than from circulatory reflexes incurred by facile intubation."

\section{Preoperative Preparation}

The technique and dosages to be given here were evolved and are based on the following preparations.

(a) Preoperative examination which included taking the exact current weight, haemoglobin, and a sharp lookout for contra-indications.

(b) Premedication which consisted of combined nembutal, morphine, and hyoscine according to the tables of Leigh and Belton (20).

(c) Outlay of equipment as follows:

1. Source and delivery of anaesthetic agents from an anaesthetic machine with single line delivery (of at least oxygen, nitrous oxide, and ether), masks with bags of appropriate sizes (29), a Stephen-Slater non-rebreathing valve (32) with a reservoir bag attached, and a syringe loaded with the calculated required amount of the pentothal-curare mixture.

The most suitable syringes for holding and measuring calculated total dosage while providing a scale fine enough for fractional maintenance doses were 20,10 , and $2 \mathrm{ml}$. sizes for patients weighing over $50 \mathrm{lb}$., 10 to $50 \mathrm{lb}$., and under $10 \mathrm{lb}$. respectively. The amount of the mixed pentothal-curare solution drawn up in readiness for a given case was one of

(i) The calculated intubation dose (approx. lb. body wt./6) plus a small amount extra (about 1/5 of intubation dose), for "single shot" procedures.

(ii) Twice the calculated intubating dose (lb. wt./3) tor longer operations. 
2. Intravenous equipment including short or medium bevelled needles (21, 20 and 19 G.) for venupuncture, arm or leg splints, and, if necessary, a venous cut-down set.

3 Intubation equipment mcluding carefully sized endotracheal tubes with connectors to fit the Stephen-Slater valve.

4 Maintenance material such as a pressure cuff, suction catheters, etc.

An assistant should be available if not actually helping in this technique. Just before induction the operating table should be put in slight Trendelenburg position to counteract the transient decrease in blood pressure that generally follows the rapid injection of pentothal (30).

\section{Technique and Dosage}

The technique and dosage for rapid injection of mixed pentothal-curare for intubation and subsequent mantenance of anaesthesia in infants and children as developed in this series of cases is presented hereunder as four consecutive phases
I. Preliminary induction for venipuncture
II. Injection and dosages for intubation
III. Maintenance
Iv. Extubation and emergence.

\section{PRELIMINARY INDUCTION FOR VENIPUNCTURE}

The child is induced carefully and smoothly by open mask insufflation with nitrous oxide (10 litres per min.) which becomes partial rebreathing or nonrebreathing (and the nitrous oxide flow is cut to $4-61 . / \mathrm{min}$.) when the mask is finally brought in contact with the face. The moment the child exhibits slight duskiness (nails or lips) oxygen is turned on to at least 20 per cent of the total flow and the skin analgesia and light hypnosis thus maintained with oxygennitrous oxıde. A limb is selected, taped to a splint, and the intravenous puncture or procaine infiltration and intravenous cut-down is performed. If 80 per cent nitrous oxide is not sufficient to "hold" the child through this, a trace of trichlorethylene is added and the nitrous oxide reduced to 70 per cent. In special cases such as respiratory hypoxia or cardlac conditions where a high oxygen flow is necessary, nitrous oxide is contra-indicated for ths phase, the venipuncture or cut-down being performed under local anaesthesia during pure oxygen alone or with a trace of trichlorethylene or ether.

\section{INJECTTON AND DOSAGES FOR INTUBATION}

The moment the needle is in place in the vein any subsidiary agent in use (trichlorethylene or others) is at once turned off. The percentage of oxygen is increased to 50 per cent (25-100 per cent) of the total flow in order to eliminate even the possibility of any hypoxia during the sudden onset of the effects of pentothal. In this regard, it is also preferable that the injection of pentothalcurare be timed so that the child shall have taken about seven breaths of the higher oxygen flow (i.e., coefficient of ventilation (4)) before the onset of the anaesthesia. The intubating dose of pentothal-curare is injected right after venipuncture. The intubation dosages of mixed pentothal-curare for the whole 
weight or age range of chldren and infants as found and computed from this series of cases are presented in Table II.

In the average child with average effects from this prenedication the minimum intubating dose will barely allow intubation, and active bucking on the tube will usually ensue. On the other hand the maximum necessary intubating dose

TABLE II

\begin{tabular}{|c|c|c|c|c|c|c|c|c|c|}
\hline \multirow{2}{*}{$\begin{array}{l}\mathrm{Wt} \\
(\mathrm{lb})\end{array}$} & \multirow{2}{*}{$\begin{array}{l}\text { App } \\
\text { age } \\
\text { (yr) }\end{array}$} & \multicolumn{3}{|c|}{$\begin{array}{l}\text { Intubating dose } \\
\text { (ml pent-curare) }\end{array}$} & \multirow{2}{*}{$\begin{array}{l}\text { Wt } \\
(\mathrm{lb})\end{array}$} & \multirow{2}{*}{$\begin{array}{c}\text { App } \\
\text { age } \\
\text { (mo) }\end{array}$} & \multicolumn{3}{|c|}{$\begin{array}{l}\text { Intubating dose } \\
\text { (ml pent-curare) }\end{array}$} \\
\hline & & $\min$ & opt & $\max$ & & & min & opt & $\max$ \\
\hline 100 & 14 & 150 & 160 & 170 & 20 & 12 & 30 & 34 & 38 \\
\hline 90 & 13 & 140 & 150 & 160 & 19 & 11 & 30 & 32 & 34 \\
\hline 80 & 12 & 130 & 140 & 150 & 18 & 10 & 28 & 30 & 32 \\
\hline 70 & 11 & 110 & 120 & 130 & 17 & 9 & 26 & 28 & 30 \\
\hline 65 & 10 & 100 & 110 & 120 & 16 & 8 & 24 & 26 & 28 \\
\hline 60 & 9 & 90 & 100 & 110 & 15 & 6 & 23 & 25 & 27 \\
\hline 55 & 8 & 80 & 90 & 100 & 14 & 4 & 22 & 24 & 26 \\
\hline 50 & $\tau$ & 70 & 80 & 90 & 13 & $3 \frac{1}{2}$ & 20 & 22 & 24 \\
\hline 45 & 6 & 65 & 80 & 85 & 12 & 3 & 18 & 20 & 22 \\
\hline 40 & 5 & 60 & 70 & 80 & 11 & $2 \frac{1}{2}$ & 16 & 18 & 20 \\
\hline 35 & 4 & 50 & 60 & 70 & 10 & 2 & 14 & 16 & 18 \\
\hline 30 & 3 & 40 & 50 & 60 & 9 & $1 \frac{1}{2}$ & 11 2 & 14 & 16 \\
\hline 28 & $2 \frac{1}{2}$ & 38 & 45 & 50 & 8 & 1 & 10 & 12 & 14 \\
\hline 26 & 2 & 36 & 40 & 44 & 7 & Birth & & $10^{?}$ & \\
\hline 24 & $1 \frac{1}{2}$ & 34 & 38 & 42 & 6 & & & & \\
\hline 20 & 1 & 30 & 34 & 38 & 5 & Prem & & $05 ?$ & \\
\hline
\end{tabular}

will usually produce somewhat more anaesthesia and relaxation than necessary but no untoward effects. The minimum dose is approximately one-tenth less and the maximum necessary dose about one-tenth more than the optimum intubating dose. In a few cases, dosages one-third greater than the optimum dose were given rapidly with no apparent harm to the child.

The optimum rapid intubating dose of mixed pentothal-curare is (see Table II) very close to $1 \mathrm{ml}$. per $6 \mathrm{lb}$. body weight for all children. This amounts to $0: 125 \mathrm{mg}$. ( 0.8 units) of curare and $4 \mathrm{mg}$. of pentothal per $\mathrm{lb}$. body weight or 5 units curare and $25 \mathrm{mg}$. pentothal per $6 \mathrm{lb}$. body weight. The optimum dose permitted easy intubation usually without subsequent bucking and was employed in all cases except where a mmimum or maximum dose was indicated. Relative indications for a minimum or maximum intubating dose are as listed in Table III.

The calculated intubating dose is injected at a rate of about 0.5 to $1.0 \mathrm{ml} . / \mathrm{sec}$. The needle is then left in the vein and the syringe taped to the limb at least until after intubation is completed. Cases with reduced cardiac reserve or output or with serious ECG disturbances and all infants should probably be injected more slowly.

The onset of pentothal anaesthesia occurs about 5 to 10 seconds after the start of the injection (decholin arm-to-tongue circulation time is 10-15 sec. in aduilts) and is marked by sudden apnoea which may be heralded by a deep 
TABLE III

\begin{tabular}{|c|c|c|c|}
\hline & Relative indications & For min dose & For max. dose* \\
\hline 1. & $\begin{array}{l}\text { Patient near either end } \\
\text { of weight and age scale }\end{array}$ & $\begin{array}{l}\text { Tiny infants } \\
\text { (under } 3 \mathrm{mo} \text { ) }\end{array}$ & $\begin{array}{l}\text { Largest children } \\
\text { (over } 11 \text { yrs) }\end{array}$ \\
\hline 2 & $\begin{array}{l}\text { Considerable disparity } \\
\text { between chronological } \\
\text { (real) and apparent (wt) } \\
\text { age }\end{array}$ & $\begin{array}{l}\text { Chronological } \\
\text { age two or more } \\
\text { steps below } \\
\text { apparent age }\end{array}$ & $\begin{array}{l}\text { Chronological } \\
\text { age two or more } \\
\text { steps more than } \\
\text { apparent age }\end{array}$ \\
\hline 3 & $\begin{array}{l}\text { Health, tone and } \\
\text { resistance }\end{array}$ & $\begin{array}{l}\text { Poor, as from } \\
\text { deranged metabolism, } \\
\text { long stay in bed, etc }\end{array}$ & $\begin{array}{l}\text { Several previous } \\
\text { anaesthetics }\end{array}$ \\
\hline 4 & Physique beyond average & Asthenic & Very robust \\
\hline 5 & Premedication effects & Depressed & Wide awake \\
\hline 6 & Duration of surgery & Very short & Long \\
\hline 7 & Speed of injection & & Slower than rapid \\
\hline
\end{tabular}

$\mathrm{N} \mathrm{B}$. When in any doubt use the larger intubating dose

*Refers to the usual maxımum necessary intubating dose which is not nearly as large as the maxımum tolerated intubating dose would be

respiration or two, and by sudden disappearance of lid reflexes and eye movement. A closed mask with partial or non-rebreathing bag attached is applied and manually held to the child's face and adequate or more than adequate controlled respiration with 50 per cent $(25-100$ per cent) oxygen in nitrous oxide begun at once. The intermittent positive pressures on the bag should be kept low (rapid and shallow) to avoid inflating the stomach. This respiration is continued right up to the initiation of laryngoscopy in order to ensure abundant pulmonary oxygen and absence of hypercarbia throughout intubation.

The optimum time for laryngoscopy and intubation seemed to be 30 to 60 seconds after injection. Laryngeal instrumentation before or after this period was very liable to result in cord closure on laryngoscopy and/or a short pe-iod of mild bucking after intubation. Early intubation (30 sec.) under the initia wave of deeper anaesthesia was favoured over later intubation $(60 \mathrm{sec}$. or more) under lightening anaesthesia. The tendency of laryngeal manipulation to end the transient hypotension of rapid barbiturate induction (30) is invoked earlier, and the objections raised against laryngoscopy and intubation under very light anaesthesia are obviated. A rough approximation of the early depths of pentothal anaesthesia and the onset of curare effects on the larynx as cobserved clinically are shown in Figure 1.

At the time selected for intubation, controlled respiration is stopped and the mask discarded from the patient's face. Laryngoscopy and intubation are immediately carried out, smoothly and quickly. In most of the patients that had received an adequate intubation dose, the vocal cords were in the cadaveric position and showed little or no motility. Mild adduction of the cords clid not 


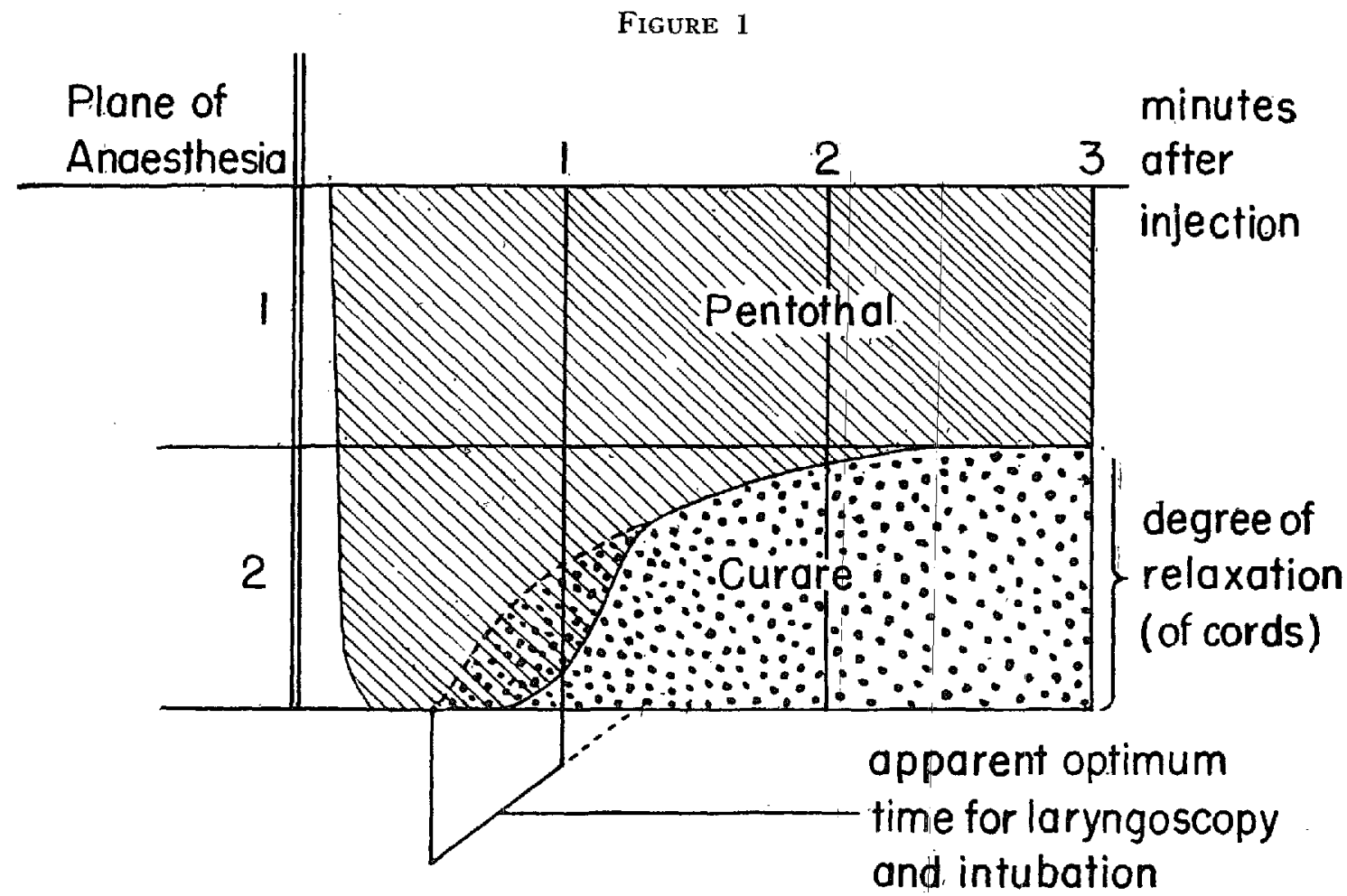

interfere with intubation, the cords being gently and readily separated by the endotracheal tube. As soon as the endotracheal tube is in, it is connected to the Stephen-Slater valve and reservoir bag and controlled respiration with nitrous oxide-oxygen is continued. If intubation is followed by more than a brief period of bucking or tight chest (so-called "bronchospasm") an additional dose ( $1 / 1 / 4$ of intubating dose) of the mixture is given. In about 10 per cent of cases the cords closed on laryngoscopic exposure and did not reopen during a waiting period of 10 seconds. In these the laryngoscope was removed without attempting intubation, the mask was reapplied and controlled respiration was continued for 30 seconds after the injection of an extra dose (approx. $1 / 4$ of intubating dose) of the mixture. Laryngoscopy and intubation were then carried out. It was felt that many of these patients exhibited laryngeal reddening (hyperirritability) and/or had not received an adequate intubating dose in the first place. In the "single shot technique" for short procedures such as tonsillectomies the needle (and syringe) is now removed from the vein. Otherwise the syringe is taped to the limb or connected to the intravenous drip for maintenance of anaesthesia by intermittent doses.

The average duration of respiratory paralysis, relaxation, and anaesthesia in children following the rapid injection of an intubating dose of pentothal-curare and under maintenance with controlled or assisted respirations with 30 per cent oxygen and 70 per cent nitrous oxide is given in rough approximation in Table IV. 
TAB́LE IV

$\begin{gathered}\text { Minutes } \\ \text { after } \\ \text { injection }\end{gathered}$
Respiration

Note Duration of pentothat anaesthesia is longer in infants under $20 \mathrm{lb}$

\section{MAINTENANCE}

(a) Of respiration. This must be assisted or controlled continuously with at least 20-30 per cent oxygen in an adequate rate of total gaseous flow (27) from a non-resistant non-rebreathing system.

(b) Of anaesthesia and relaxation. Depending especially on the type and requirements of the surgery most of the patients were carried for 10 to 30 minutes after intubation before supplementary anaesthesia was needed. In abdominal surgery a supplementa or "maintenance" dose of pentothal-curare was needed before opening the peritoneum.

In short $(1 / 4-3 / 4$ hr. ) non-abdominal procedures such as the removal of adenoids and tonsils a "single shot" (the intubation dosage) was all the anaesthesia necessary in addition to the nitrous oxide. On insertion of the endotracheal tube the needle was removed, the chuld's arms were abducted to the sides and the operation was begun at once. If excessive lightening occurred before the end of the operation, anaesthesia and relaxation were readily "stretched out" for an extra 5 to 15 minutes merely by adding a trace of ether or trichlorethylene to the nutrous oxide and oxygen mixture. The signs of insufficient anaesthesia and relaxation indicating the need for maintenance doses were similar to those in adults. The agents used to maintain first plane anaesthesia and the required degree of relaxation subsequent to that of the intubation dose of pentothalcurare were pentothal-curare-nitrous oxide alone or supplemented by ether or trichlorethylene, or ether or trichlorethylene alone.

Pentothal-curare-nitrous oxide was generally used as the sole maintenance combination in all of the cases until partial or complete changeover to inhalation agents became desirable. While continuing to administer nitrous oxide and oxygen throughout the operation, a maintenance dose of mixed pentothal-curare was injected whenever indicated by the onset of signs of lightening. The optimum 
intermittent maintenance dose was found to be $1 / 10$ to $1 / 5$ the original intubating dose. The smaller dose $(1 / 10)$ was favoured in infants, near the end of operations or in the presence of supplementation with a trace of one of the other anaesthetic agents. The larger dose (1/5) was favoured in older children, in the early phases especially of long operations or where the signs of lightening were pronounced. The interval between doses averaged 20 to 30 minutes, with progressive lengthening between successive doses especially in infants. The average amount of pentothal-curare needed to maintain plane 1 anaesthesia and adequate relaxation for the longer operations is depicted in Table $\mathrm{V}$.

TABLE $V$

\begin{tabular}{c|cc}
\hline $\begin{array}{c}\text { Duration of } \\
\text { operation }\end{array}$ & $\begin{array}{c}\text { Maximum required maintenance } \\
\text { dose (expressed as fraction } \\
\text { of intubating dose) }\end{array}$ \\
\hline & Children & Infants \\
\hline 2 hours & $\frac{1}{2}$ & $\frac{\overline{1}}{4}$ \\
4 hours & 1 & $\frac{1}{2}$ \\
\hline
\end{tabular}

The maximum amount of pentothal-curare that could be safely administered or in other words the tolerance limit to pentothal in any given case was assumed to have been reached with the advent of any one or more of the following signs: (i) Downward trend in blood pressure not due to some other cause such as deep anaesthesia or the bradycardia of insufficient atropinization.

(ii) Increasing or excessive respiratory tract secretions.

(iii) When the sum of the maintenance doses equalled the intubating dosage in children or one-half of the intubating dose in infants.

The maximum tolerated amount of pentothal-curare was reached in but a few cases because only an occasional operation is of sufficient duration to need it. The course of anaesthesia was smooth and free of metabolic disturbances or the effects of deep anaesthesia. Postoperative recovery and emergence, however, was liable to be slow ( $1 / 2 \mathrm{hr}$. or so) unless the last maintenance dose of pentothalcurare was given over $1 / 2$ to 1 hour before the end of surgery. In order to avoid this problem the maintenance dosage of pentothal-curare was considerably reduced by the supplementary addition of an inhalation agent for the latter half and/or especially during the withdrawal phase of operations.

At some point between intubation and the end of surgery it was usually found advantageous and occasionally necessary to reduce or discontinue further pentothal-curare with a partial or complete changeover to ether, trichlorethylene, or cyclopropane. The introduction of the other agent(s) must be cautious and gradual beginning with a trace and then a slow increase of the concentration only as indicated by signs of lightening as the pentothal-curare wears thin. A constant observation and important advantage was the relatively great prolongation of light anaesthesia and relaxation, up to one hour after the last dose of pentothal-curare, that could be obtained from onlly a trace or small concentration ("subtoxic dose") of ether or trichlorethylene added to the oxygen-nitrous oxide flow. From experience in this series the following conditions appeared 
advantageous or as definite indications for partial and occasionally complete supplementations with an inhalation agent:

(i) To "stretch out" anaesthesia in those operations that extend beyond the time provided by the intubating dose of pentothal-curare in the "single shot" technique for short operations.

(11) In all cases where maintenance with pentothal-curare alone is not specifically desired or: where the use of the mhalation agents is not contraindicated, the maintenance dosage of pentothal-curare can be kept well. below the maximum and rapid emergence facilitated far out of proportion to the relatively small amount of inhalation agent(s) added. Partial supple. mentation with a trace of ether or trichlorethylene was therefore begun shortly after intubation in short or medium length operations especially in infants and young children and at about the midpoint of long operations.

(w1) Pentothal-curare maintenance should be discontinued altogether in favour of partial leading to complete supplementation with an inhalation agent $3 / 4,1,1 \frac{1}{2}$, and 2 hours before the end of surgery in children, $20 \mathrm{lb}$. infants, $15 \mathrm{lb}$ infants and $7 \mathrm{lb}$. infants respectively in order to avoid delayed emergence and residual light pentothal hypnosis in "the postoperative period. In long operations pentothal-curare maintenance must be discontinued before this if the maximum tolerated dose is reached. Even where the resultant duration of complete supplementation was considerable, the sparing effect by the previous pentothal-curare was decidedly manifest in the smooth and immediate postoperative emergence and relative absence of disturbed metabol.sm.

(iv) Where a rich oxygen flow is desired the reduction or discontinuation of nitrous oxide and its analgesia requiries substitution with a trace of inhalation agent (or else small maintenance doses of Demerol) to avoid an increasing pentothal-cu_are demand.

(c) Of colour, pulse and blood pressure. Throughout maintenance with pentothal-curare-nitrous oxide alone or supplemented by a small amount of another agent the face seemed to exhrbit a slight paleness but the colour of the lips, nalls, and soles of the feet remained normal. The regular and well-filled pulse maintained at an even $80(80-90) / \mathrm{min}$. was a welcome contrast to the usual ether pulse. The blood pressure remained a steady normal or low normal, thus imposing a lesser cardiac load than the usually elevated pressure from ether or cyclopropane anaesthesia.

(d) Of drug, fuid, and electrolyte needs. Maintenance of basal atropinization and analgesia with an occasional small intravenous dose of atropine and Demerol was carried out where indicated. A very small supplementary dose of curare was added near the end of an occasional abdominal case to maintain relaxation while lightening anaesthesia toward emergence. Fluids and electrolytes were given as required.

\section{EXTUBATION AND EMERGENCE}

All agents except nitrous oxide and oxygen were tapered to a minimum or discontinued entirely at the earliest moment allowed by the surgical procedure in order to secure definite signs of lightening during the last few skin sutures. 
The concentration of nitrous oxide was increased to 80 per cent to substitute for the dwindling amounts of the other agents in maintenance of this early reactive level of anaesthesia. Unexpected signs of excessive reactivity such as a tendency to buck on the tube were controlled by immediate introduction of a moderate concentration of ether with shallow and rapid rather than deep and slow bag pressures.

The rare cardiac arrest $(24,26)$ from suction and extubation under light anaesthesia is due to aggravation of the reflex electrocardiographic disturbances (11) by hypoxıa (17), hypercarbia, roughness, etc. as during intubation. The following procedure of suction and extubation in four serial steps is used to elıminate or safely minimize these factors and thus obviate cardiac arrest.

1. The nitrous oxade is turned off, replaced with pure oxygen $(61 . / \mathrm{min}$.), and the lungs are inflated at least seven times. If the patient showed signs of bucking on the tube, inflations were done rapidly and the third step begun at once. On the other hand, if little or no signs of lightening were present these inflations were carried out at a rate of about seven per minute until the signs were definite.

2 Oropharyngeal suction is performed with a good-sized rubber catheter, which is then replaced on the suction line by a catheter considerably smaller than the endotracheal tube.

3 The Stephen-Slater valve is removed and while suction is pinched off the catheter is quickly inserted down the endotracheal tube unto the right main bronchus. At the moment suction is allowed to continue the endotracheal tube and after-coming catheter are gently withdrawn in a single movement requiring 1 to 2 seconds

4. A mask is applied to the face and the lungs are immediately inflated several times with pure oxygen The occasional but mild arid transient laryngeal spasm was easily overcome with oxygen under positive pressure. Awakening and deeper breathing are hastened by pain stimulı If necessary these inflations are continued at about only three or four per minute to allow some carbon dioxide buld-up until breathing is adequate and the child emergent (opens eyes on command and/or phonates and moves limbs considerably on painful stimulation). Only then is a child considered ready to leave the operating room.

The smoothness and rapidity of extubation and emergence are increased considerably as experience is gained. The ideal objective seemed to be a state of light and rapidly waning anaesthesia permitting oxygenation, suction, and extubation without bucking as the last skin suture is inserted, and followed by emergence to or near a state of wakefulness with adequate breathing within 3 minutes after extubation. This was achieved in about 50 per cent of the cases in each of the age groups, with about one-half of these patients being almost fully awake one minute after extubation. Owing mainly to mexperience in the earlier cases of each age group, the remaining 50 per cent of patients either emerged too quickly and bucked on the endotracheal tube or emerged too slowly and required assisted respiration with oxygen for 3 to 15 minutes after extubation before sufficient breathing and consciousness had returned.

The colour and pulse of every patient remained normal throughout and there 
were no cardiac stoppages. Patients left the operating room only when they could be roused (emergent) and were breathing adequately.

\section{Postoperative Observation and Care}

The final and a very important margin of safety is provided by sending every case to a fully equipped recovery room or its equivalent for a period of close and expert nursing survellance. Since delayed and potentially serious postoperative depression from both pentothal and curare has been reported in adults, It was felt that all patients including even those wide awake shortly after extubation should be kept here for a minimum of $1 / 2$ hour for older children and 1 hour for infants. As an added precaution or guard, tiny infants were usually placed in an oxygen tent especially after major surgery or peroral endoscopy. The slightest sign of deterioration of respiration or colour would of course call for immediate attention to the aurway and the administration of oxygen, preferably by assisted respiration from a bag and mask, through the depressed phase. Although there were no cases of delayed or prolonged depression requiring iespiratory assistance in this series, Noble (22) reports one child with prolonged curare paralysis following this technique Adequate artificial respiration resulted in an uneventful recovery whereas postoperative neglect would have resulted in an unnecessary fatality.

After 1eaching the recovery room nearly all patients not previously awake could be roused to wakefulness within 10 or 15 minutes If left undisturbed the majority, especially the younger ones, lapsed into a light "normal" sleep lasting 30 to 60 minutes, from which they awoke quietly and refreshed. The normal colour, pulse, and respuration throughout the recovery period contrasted sharply with the flushed appearance, rapid pulse, and acidotic breathing after ordinary ether anaesthesia. There was no vomiting and very little posioperative restlessness except where a sizable amount of ether had been used for maintenance. Restlessness was otherwise usually due to pain and easily controlled with a very small intramuscular dose of Demerol There were no laryngospastic episodes, atelectasis, or other postoperatıve complications. Preoperatıve systematıc illnéss such as fever, acidosis, etc. appeared very definitely improved on emergence. The nursing and other personnel concerned felt that recovery time and troubles (but not responsibilityl) were considerably less than with other types of paediatric anaesthesia.

\section{SUMMARY}

Some of the advantages of mixed pentothal-curare (Baird's solution) and nitrous oxide anaesthesia over the other types of general anaesthesia in adults are noted and the need in paediatric anaesthesia for a method with similar advantages was peinted out. The main object of this prelimmary investigation was to seek a basic dosage scale of mixed pentothal-curare (ml./lb. body wt.) in children for' à specific purpose (rapid injection for orotiacheal intubation) so that this technique of anaesthesia and its advantages might be extended into the paedratıic field. A surprisingly constant and accurate scale was found, and so it was possible to modify the well-known rapid injection technique for advantageous use in children and infants. 
The indications, contra-indications, and possible complications of this method in children were assumed to be basically similar to those in adults and those fóm to differ significantly from experience with adults or felt to be of special importance in paediatric anaesthesia are emphasized. The technique itself $1 \mathrm{~s}$, except for the added prelıminary induction phase and quantitative modifications, similar to that employed in adults It is presented in much delail, however, in order that the clinical effects of each step and the management thereof in children may be fully understood and the margins of safety guarded. Postoperative observation and care are șmilarly emphasized.

The amounts of pentothal-curare required for rapid intubation and for maintenance of children and infants and the clinical effects thereof were remarkably uniform. The salient findings are as follows:

1. The optimum mixture for $100 \mathrm{lb}$. children down to about $20 \mathrm{lb}$. unfants is that of Baird's solution ( $25 \mathrm{mgm}$. pentothal with 5 units curare per $\mathrm{ml}$. of solution). Since the duration of the effects of pentothal increases and those of curare remain about the same in progressively younger infants, a mixture with a smaller proportion of pentothal ( 15 or $20 \mathrm{mgm} . / \mathrm{rnl}$.) would likely be more suitable for them.

2. The tolerance of all of the children and infants to a rapidly injected dose of the pentothal-curare sufficient for intubation was excellent and probably equivalent to that of adults The tolerance displayed to subsequent total maintenance dosage by 20 to $100 \mathrm{lb}$ patients appeared to be about one-half that of adults, and by infants under $20 \mathrm{lb}$. it was probably about one-quarter that of adults.

3. The dose of rapidly injected pentothal-curare needed for intubation was very closely related to body weight and could therefore be predicted with safety and much greater accuracy than in adults. The amount used for maintenance seemed at least as closely related to body weight as in adults.

4. The optimum rapid intubation dose of millilitres of pentothal-curare mixture (1) for children and infants is $\mathrm{lb}$. wt $/ 6, \pm 1 / 10$ for variables. The optimum intermittent maintenance dose is about $1 / 10$ to $1 / 5$ the intubating dose given every 15 to 30 minutes. The maximum tolerated total maintenance dosage in children seems to be equal to the intubation dose and in infants it is only one-half of the intubating dose.

5. The degree and duration of pentothal-curare anaesthesia and relaxation in children are comparable to those observed in adults.

6. The amount of pentothal-curare needed for mantenance can be greatly reduced by a disproportionately small amount (trace) of ether or trichlorethylene. This was found to be particularly useful near the end of operations in the interests of rapid emergence and in halving the total maintenance dosage of pentothalcurare in lengthy procedures.

Throughout this investigation all of the well-known advantages seen in adults from rapid intubation and maintenance with pentothal-curare-nitrous oxide were obtained. The disadvantages and possible dlangers in children are easily circumvented by knowledgeable and careful selection and management. 


\section{COMMENTS}

Apart from the general dosage scale of pentothal-curare, the findings and observations in the limited number of cases of this investigation must be considered prelmmary and provisıonal until many more cases have been reported, preferably by several investigators. Even the dosage prosortions and range may require some revision especially for small infants. Fur hermore, various combinations of the other relaxants and short-actung barbiturates could be similarly investigated and employed in paediatric anaesthesia, each of which might more exactly' fulfil the particular needs of special cases.

The basic prerequisites for the safe employment of rapid intubation and maintenance with barbiturate-relaxint-nitrous oxide anaesthesia in children and infants are:

(a) Management throughout only by those with the knowledge, experience, and expert technical training to handle all of the phases and possible problems.

(b) A beginning with older children and then a gradual descent of the paediatric weight-age scale as expenence is gained.

(c) Adequate assisted or preferably controlled respiration from rapid injection to emergence.

(d) Care to avoid overdosage in mantenance especially of long procedures.

(e) Expert and careful postoperative care and observation in a well-equipped recovery room or its equivalent.

Neglect of any of these prerequisites could result in fatalities which are apt to be blamed on the inanimate agents themselves rather than on those responsible for their safe administration and management An example of this is found in a recent statistical survey (3) wherem Beecher focuses the spotlight of blame for anaesthetic deaths on the muscle relaxants. Griffith (13) deftly places his finger on both the real cause and the prevention of such deaths in one sentence, "If Beecher's survey proves anything, I think it proves that there is need for more good anaesthetssts, trained to use their brains intelligently, individually and on a level with the exacting standards of good medicine." The results of this investagation are offered in this light and in the hope that children will not have to go on paying the price of ether morbidity for safety in anaesthesia.

\section{ADDENDUM}

Since completion of this investigation, the technique described has been employed in over 400 children by Dr. A B Noble of Kingston, Ontario, and in a large number of children by Dr. H. M. Slater and associates of Montreal. Appreciation is expressed to Dr. Slater for his valuable advice and criticism.

\section{RÉSUMÉ}

Quelques-uns des avantages d'un mélange de pentothal-curare (Solution de Baird) et de protoxyde d'azote employé en anesthésie sur les autres types d'anesthétiques chez les adultes sont notés et le besoin en pédiatrie d'une méthode anesthésique comportant des avantages semblables est indiqué. Le 
but principal de cette enquête préliminaure était l'établissement d'une échelle fondamentale de dosages de pentothal-curare mélangé (cc./lb poids-corps) à l'intention des enfants (injection rapide pour l'intubation orotrachéale) de façon à ce que cette technrque d'anesthésie et ses avantages pussent s'appliquer au domaine de la pédiatrie. Une échelle étonnamment constante et précise a été trouvée, et ainsi ll a été possıble de modifier la technıque bien connue d'injection rapide pour l'appliquer avantageusement aux enfants et bébés

On a présumé que les indications, contre-indications et les complications possibles de cette méthode chez les enfants étarent fondamentalement semblables à celles des adultes. Nous ne présentons que celles qui diffèrent d'une manière sıgnificative de l'expérrence chez les adultes ou quı semblent offrur une importance spéciale pour l'anesthésıe en pédiatrie. La technique elle-même, à l'exception de la phase supplémentaire d'induction prélımıarre et des modifications quantitatives, est elle-même identıque à celle employée chez les adultes. Elle est présentée cependant en grands détals, pour que les effets clinıques de chaque phase, et le traitement subséquent des enfants soient bien compris et la marge de sécurité bren observée Les observations et les soins après l'opération sont également soulignés

Les quantités de pentothal-curare nécessaires pour l'intubation rapıde et pour le maintien des enfants et des bébés et les effets clınıques quı en découlent ont été remarquablement uniformes. Les données salllantes sont les survantes.

1 Le mélange optımum pour les enfants de 100 livres jusqu'aux bébés de 20 hvres est celle de la solution de Baird ( $25 \mathrm{mgm}$ de pentothal avec 5 unités de curare par cc de la solution). Etant donné que la durée des effets du pentothal augmente et que celle du curare reste à peu près la même chez les enfants progressivement plus jeunes, un mélange d'une proportion plus petite de pentothal ( 15 ou $20 \mathrm{mgm} / \mathrm{cc}$ ) semblerait être plus convenable dans leur cas.

2. La tolérance de tous les enfants et des bébés à une injection rapide d'une dose de pentothal-curare suffisante pour l'intubation était excellente et probablement équivalente à celle des adultes. La tolérance à des doses totales maintenues par des patients de 20 à 100 livres semblait être environ la moitié de celle des adultes, et celle des bébés en-dessous de 20 livres était probablement un quart environ de celle des adultes.

3. La dose rapidement injectée de pentothal-curare nécessaire à l'intubation était en rapport étroit avec le poids du corps et pouvart être prédite par conséquent avec sécurité et beaucoup plus de précision que chez les adultes. La quantité employée pour la dose d'entretıen semblart dụ moins aussı relative au pords du corps que chez les adultes

$4 \mathrm{La}$ dose optıma en centimètres cubes de solution de pentothal-curare nécessaire à l'intubation rapide pour les enfants ef les bébés est livre-poids /6, $\pm 1 / 10$ pour les variables La dose intermittente optıma de maintien est environ $1 / 10$ à $1 / 5$ de la dose d'intubation adminıstrée toutes les 15 à 30 minutes La dose totale de mantien maxima tolérée pour les enfants semble être égale à la dose d'intubation et chez les bébés elle n'est que la moitié de la dose d'intubation.

5. Le degré et la durée de l'anesthésıe au pentothal-curare et le relâchement chez les enfants sont comparables à ceux observés chez les adultes 
6. La quantité de pentothal-curare nécessaire pour le maintien peut être considérablement réduite par l'addition d'une quantité extrêmement petite (une trace) d'éther ou de trichloréthylène. Ceci s'est avéré particulièrement utile vers la fin des opérations, en vue d'une émergence rapide et pour réduire de moitié la dose totale de mantien de pentothal-curare dans les cas de longs procéc és.

Pendant cette enquête tous les avantages bien connus de l'intubation rap de chez les adultes et le maintien au pentothal-curare-protoxyde d'azote ont été obtenus. Les désavantages et les dangers possibles pour les enfants sont facilement évités grâce à une sélection et une conduite intelligente et soignée de l'anesthésıe.

\section{Commentaires}

A part l'échelle générale de dosages du pentothal-curare, les données et les observations dans le nombre limité de cas de cette enquête doivent être considérées comme étant prélimınaires et provisoires jusquà ce que beaucoup plus de cas a1ent été rapportés, et préférablement par plusieurs chercheurs. Les proportions et l'étendue même de dosage exigeront peut-être une révision, particulièrement pour les petits bébés. En plus, diverses combinaisons d'autres relaxants et de barbituriques à courte action pourraient être étudées et servir comme anesthétıques en pédıatrie, et il se pourrait que chacun réponde plus exactement aux exigences particulières de cas spéciaux.

Les conditions préalables fondamentales pour l'emploi sûr de l'intubation rapide, et le mantien en anesthésie utilisant les relaxants barbituriques et le protoxyde d'azote chez les enfants et les bébés sont:

(a) Conduite de l'anesthésie par ceux-là seulement qui possèdent les connaissances, l'expérience et l'entraînement technique experts nécessaires pour parer à toutes les phases et les problèmes possibles.

(b) On commencera avec les enfants plus âgés et on descendra alors graduellement l'échelle poids-âge de pédıatrie à mesure qu'on gagnera de l'expérience.

(c) Une respiration assistée adéquatement ou mieux, contrôlée, sera instalée de l'injection rapide à l'émergence.

(d) Prendre soin d'éviter un dosage trop fort pour le maintien surtout dans le cas de longs procédés.

(e) Soins et observations experts et soignés après l’opération, dans une salle de recouvrance bien équippée ou son équivalent.

La néglıgence de ces 'conditions peut causer la mort, et on aura tendance à blâmer les agents inanimés eux-même plutôt que ceux qui sont responsables du soin et de l'administration de ces agents On en trouve un exemple dans une revue statistıque récente ( 3 ) où Beecher attribue aux relaxants musculaires le blâme pour les mortalités résultant de l'anesthésie. Griffith très adroitement indıque en une phrase la vraie cause et la prévention de telles mortalités, "Si la revue de Beecher prouve quoi que ce soit, je crois qu'elle prouve que nous avons besoin d'un plus grand nombre d'anesthésistes, entraînés afin d'employer intelligemment et indıviduellement leurs connaissances et suivant les exigences les plus élevées de la bonne médecine." Les résultats de cette étude sont présentés dans cet esprit et dans l'espoir que les enfants ne continueront pas à payer le prix de la morbidité causée par l'éther pour la sécurité en anesthésie. 
ADDENDA

Depuis la fin de cette enquête, la technıque décrite a été employée dans plus de 400 cas d'enfants par le Dr A B. Noble de Kingston, Ontarıo, et dans un grand nombre de cas d'enfants par le Dr. H M Slater et ses collaborateurs à Montréal. Nous exprimons notre reconnaıssance au Dr. Slater pour ses précieux conseuls et critiques.

\section{REFERENCES}

1. BaIRD, J W. Pentothal-Curare Mixture Anesthesiology 8 75-79 (1947)

2 Baumgarten, O. \& Betcher, A $M$ The Use of the Non-Rebreathing Method of Anesthesia. Anesthesiology 15(2)- 188-195 (1954)

3. Beecher, H K Time, 64(4).62 (26 July, 1954)

4. Best, C H \& TAYLon, N B The Physiological Basis of Medical Practice. 5th ed., Baltımore: The Willams \& Wilkıns Company (1950).

5. Bourne, Wesley \& Stemue, R. L The Excretion of Phosphoric Acid during Anaesthesia. J A M.A 83117 (1924).

6 Brown, E. B, Jr \& Mrller, F Ventricular Fibrillation following a Rapid Fall in Alveolar Carbon Dioxıde Concentration Am J Physiol 169 56-60 (1952).

7 - Tolerance of Dog Heart to Carbon Dioxıde Am J Physiol 170 550-554 (1952).

8. Bunstein, C. L Fundamental Consideration in Anesthesia New York The Macmillan Company (1950)

9. 'Burstein, C L, Lopinto, F J \& Newman, W. Electrocardiographic Studies during Endotracheal Intubation. I Effects during Usual Routıne Technics Anesthesiology $11(2)$. 224-237 (1950).

10 Colon-Yondon, E, Macknell, T. N, \& Stone, H H An Evaluation of the Use of Thiopental and Decamethonium Bromide for Rapid Endotracheal Intubation. Anesthesiology 14(3). 255-277 (1953).

11. Converse, J. G., Landmesser, C. M, \& Harmel, M. H Electrocardiographic Changes during Extubation. Anesthesiology 13(2) 163-168 (1952).

12. Carnow, D C. \& Pratt, E L Fluid Therapy. J A M.A. 143(4) 365-373 (1950).

13. Griffrtr, H. R. Succinylcholine-A Controllable Muscle Relaxant. C.M.A J. 71(1) 28-31 (1954).

14. Griffiti, H. R. \& Johnson, G E The Use of Curare in Ceneral Anaesthesia Anesthesiology 3 418-420 (July, 1942)

15. Hudon, F. \& Jacques, A L'hibernation artificielle Proc Canad. Anaesth. Soc., 1953: $39-43$.

16. Jacques, A. L'anesthésie au pentothal-curare-protoxyde d'azote Laval méd. I3(10): 1252 (décembre 1948).

17. Kergin, F. J, Bean, D. M \& Paul, W. J. Thoracic Surg. 17709 (1948)

18. King, B. D., Elder, I D., Proctor, D. F., \& Drupps, R. D. Reflex Circulatory Responses to Tracheal Intubation performed under Topical Anesthesia Anesthesiology 15(3). 231-238 (1954).

19. Krumperman, LeRoy W., Long, J H , \& Lachman, R J The Changes in Blood Gases associated with Methods of Induction for Endotracheal Anesthesia (To be published).

20. Leigh, $M$ ì \& Belton, M K Pediatnc Anesthes,ia. New York: The Macmillan Company (1948).

21. Marples, E. \& Lippard, V. W. Acid-Base Balance of Newborn Infants. Am. J. Dis Child. 44: 31 (1932).

22. Noble, A. B. Personal communication.

23. Quaster, J H. Brochemucal Aspects of Narcosis Anesth \& Analg 31(3): 151-163 (1952).

24. Raffan, A: W. Reflex Cardiac Arrest under Anaesthesia. Anaesthesia $9(2): 116-119$ (1954). 
25. Rosner, S, Newman, W.', \& Bunstein, C. L. Electrocardiographic Studles during Endotracheal Intubation. VI. Effects during Anesthesia with Thiopental Sodivm combined with a Muscle Relaxant. Anesthesiology 14(6). 591-595 (1953).

26 Schumacker, H B., \& Hampton, L. J Cardiac Arrest on Extubation. J. Thcracic Surg. 21.48 (1951).

27 Slater, $H$ M Physiological Requirements in Equipment related to Anatomical Factors in chldren. Proc. Canad. Anaesth. Soc, 1953. 103-111.

28 Stehle, $R$ L \& Bourne, Wescey. Concerning the Mechanısm of Acidosis in Anaesthesia. J. Biol. Chem. 60: 17-29 (1924).

29 Stephen, C R. Fhysiological Factors of Significance in Pediatric Anaesthesid. C M A J. $63 \quad 109-112(1950)$.

30 Stephen, C. R, Martin, R, \& Nowill, W. K Cardıovascular Reactions of Surital, Pentothal or Evipal combined with Muscle Relaxants for Rapid Anesthesia Induction Anesth. \& Analg 32(6): 361-369 (1953)

31 Stephen, C. R. \& Slateh, H. M. Agents and Techniques employed in Pediatric Anaesthesia. Anaesth. \& Analg. 29(5). 254-262 (1950)

32. - - A Non-Resisting, Non-Rebreathing Valve. Anesthesiology 9 550-552 (1948).

33 Travers, T. \& Burt, E M. Post-Anaesthetic Acidosis. M J. Australı 2. 709 (1929).

34. Volprrto, P P Experiences with Ultra-Short Acting Intravenous Barbiturates combined with Decamethonium Bromide for Endotracheal Intubation Anesthesiology 12(5): 648-655 (1951).

35 Young, W G, Jr, Sealx, W. C., Harris, J S, \& Botwin, A Effects of Hypercapnia and Hypoxaa on Response of Heart to Vagal Stımulation. Surg, Gynec \& Obst. 93 51-55 (1951) 